\section{The Challenge of the Future as Viewed by a Rancher ${ }^{1}$}

\section{A. P. ATKINS}

O. J. Ranch, Guymon, Oklahoma

More than a century ago, Alfred Tennyson observed, "The old order changeth, yielding place to new." The challenge of the future is perpetual, and changes have characterized the western livestock industry since its inception. The hide and tallow factories of the Texas Gulf Coast went out of business when the trail herds found northern markets. The railroads which replaced the cattle trails are now being superseded by fleets of cattle trucks on modern highways. This increased mobility of livestock has contributed to other and equally important innovations.

The meat packers are abandoning obsolete plants on the old terminal markets and building new ones in proximity to auction rings and feedlots which did not even exist ten or twenty years ago. Meats that once were preserved by salting are refrigerated

1 Presented at the symposium on "How We May Meet the Challenge of the Future" during the Seventeenth Annual Meeting, American Society of Range Management, Wichita, Kansas, February 10-14, 1964. today as a matter of course; tomorrow they may be irradiated. The "butcher shop" has become a supermarket, buying carcasses on specifications; the goal is to offer the housewife packaged cuts as uniform as cans of tomatoes and available every day of the year. One of the major meat packers appears to have developed a successful tenderizing process which has no objectionable odor or flavor. Further progress in this direction might eliminate a long and expensive feeding period in a drylot, while producing an acceptable light carcass without excessive fat.

\section{Beef Types}

We who are in the business of producing commercial cattle are not impressed by pedigrees and showring ribbons which do not reflect utility and performance. If we want entertainment, we can find more action at a rodeo than at a stock show, but as a rule neither champion bulls nor champion cowboys are very useful on a ranch. The hypothetical relationship between showring standards and beef improvement was appropriately refuted a few years ago when the "comprest" fad resulted in an epidemic of dwarf calves. At about the same time, hybrid cattle proved their superiority in certain regions, and changes in dietary habits caused consumer complaints against excessively fat beef. These developments created a serious challenge to the popularity of the established breeds and their registry associations. As a result, emphasis is now being placed on gainability and carcass evaluation, and attempts are being made to revise grade standards. As yet there is no general agreement as to the ideal beef type of the future, but new models are already under development, including a number of breed crosses. One breeder has already announced his goal: to produce weaner calves which will weigh a thousand pounds and be ready to butcher. Whatever characteristics may ultimately prove acceptable, their development will be accelerated by artificial insemination. In spite of its practical limitations, AI offers definite advantages for proliferation and uniformity under favorable conditions.

\section{Hazards and Solutions}

The principal hazards of ranching can be summed up in three words: Weather, Markets, and Disease. Advances in veterinary science have reduced the 
disease hazard to third place. Fluctuations of the cattle market can result from many causes, including the size of the consumer's paycheck, and the competition of other foods; fundamentally it is a matter of supply versus demand for a perishable commodity. Weather is our greatest hazard because it directly influences the amount of our product as well as the price we receive.

This business of converting grass into beef, as I have known it, is a wonderful occupation in the years when blizzards don't hit you at calving time, and when it rains just when you need it for grass or wheat pasture. Those are the years when the extra pounds cover up mistakes in management, and even cattle which were bought too high can show a small profit. Those are the years when bankers are friendly people and everybody on Main Street buys a pair of boots and gets into the cattle business.

But there are also the years that we don't like to talk about except to brag that we lived through them. Every experienced cattleman is familiar with the consequences of drouth in terms of stunted grass, underweight cattle, depressed markets, and astronomical feed bills. Unfortunately, the difference between a short "dry spell" and a drouth is only the cumulative effect, and by the time you can definitely identify a real drouth, it is too late to prepare for it.

Every experienced rancher finds solutions for the practical problems of his particular area. They may not be the best solutions, they may not be successful in some other area, and they may not even be accepted by some of his neighbors. My own suggestions and predictions are offered with no pretense of infallibility, but with the conviction that satisfactory progress in range management can only be achieved through the combined experience and knowledge of all participating vocations.

I have found that acquiring a ranch is something like getting married. In either instance a man finds that he has to make some concessions to fit the individual case, and only personal experience can provide a successful formula for a satisfactory relationship.

As a general rule, I prefer to stock tall grass with cows and short grass with calves and yearlings. While readily admitting that there are many successful exceptions to that theory, my reasoning is this: a cow's paunch has the capacity to handle coarse forage with a relatively low nutritive value. By contrast, a small animal requires a more concentrated ration. In time of drouth and feed shortage, little cattle have a considerable advantage.

It's been a long time since I have heard anyone in this organization apply the term "normal" to anything connected with the Great Plains. I hope we will continue to regard that adjective with the suspicion which it deserves, and recognize that nothing is normal about our climate except an extreme variation of conditions. Under good management, forage production on our ranges can vary at least $50 \%$ because of the amount and distribution of rainfall. Statistical averages have no relationship to specific years. They remind me of the non-swimmer who was six feet tall and who tried to wade across a river whose average depth was only four feet. The actual depth varied from one to seven feet, and he drowned in the seven foot area. I think there is general agreement in this group that the key to successful management of our ranges is flexibility combined with a consistent policy of keeping a reserve of grass. It must be admitted that this places a severe handicap on the small operator with limited resources.
I suggest that his handicap is intensified if he insists on "marrying" a herd of cows. This type of stockman is the first to suffer from drouth, and his winter feed bill often equals or even exceeds the value of a calf crop. If I were a county agent or an SCS planner, I think I would recommend to many small operators the substitution of weaner calves, varying in number according to available forage. Calves should produce more pounds of beef per acre, and an adjustment of numbers would be easier to achieve.

While it is generally assumed that the quality of our cattle has improved over the years, we still have a lot of cattle that are commonly referred to as "plain." When I was an Animal Husbandry student, I got the impression that plain cattle were in some way socially unacceptable, and were expected to disappear like the longhorns. Now, forty years later, they are still available in quantity, and while their lighter weaning weights and lower price per pound would indicate that they are financial liabilities to their breeders, these same characteristics frequently make them attractive to growers and feeders who are more interested in profit than appearance. A competent buyer can put together a drove which will make excellent gains and satisfactory grade. Perhaps they are better cattle than the plain cattle of forty years ago, but they are still plain cattle by comparison, and I suspect that many of us will find them useful for some time to come. There might be an analogy in the careers of Tiffany and Woolworth, both of whom have been successful in selling jewelry, although to different clienteles.

\section{Other Land Values}

In addition to the production of livestock, our grazing lands are valuable watersheds. Many 
of them are sources of lumber, petroleum, and an assortment of minerals. As recreation areas, they attract hunters, fishermen, and tourists. Increasing competition for the use and control of grazing lands can be anticipated, and the rancher must expect to pay a high price, either in investment and taxes, or in rent, in order to stay in business.

However natural and proper the desire of urban people to enjoy unlimited access to "The Great Outdoors", we are beginning to realize that there isn't enough outdoors left to accommodate our expanding population. As an indication, one area in Oklahoma which was opened to deer hunting last fall reported hunters at a rate of something like one to every six acres. In about one more generation, I expect public hunting, as we know it, to be abolished. Big game will be confined to park areas, for exhibition only. Bird hunting will be largely limited to private preserves. The transition will be prolonged and painful, but it appears inevitable. It will be difficult to dispel illusions created by long exposure to wild west novels, television serials, and rodeos. Wildlife organizations will continue to resist the posting of privately owned lands, and will stoutly defend the multiple use policy of public land administration as long as hunting and fishing enjoy a privileged status. They will receive encouragement from well financed and politically powerful commercial interests, including Chambers of Commerce, motels, service stations, and suppliers of guns, fishing tackle, and camping equipment.

Perhaps the Livestock Associations could profitably devote more attention to public relations in order to increase respect for landowners' legitimate rights and property. Ignorance and carelessness on the part of even a small minority of "sportsmen" make it difficult for the most generously inclined ranchers to reach a reasonable accommodation of interests. On the OJ Ranch, which consists entirely of deeded land, we encouraged some of our neighbors to organize a sportsman's club. We agreed to allow them exclusive hunting and fishing privileges in return for their help in policing the ranch. This appears to be a satisfactory arrangement under our circumstances, although manifestly impractical in many cases.

Eventually, I think the sheer pressures of population and economic values will determine the outcome, and hunting and fishing will become very expensive pastimes which relatively few people will be able to enjoy.

\section{Research}

The transfer of agricultural land into non-productive uses is proceeding at an estimated rate of a million acres per year. $\mathrm{Ob}$ viously, if our grazing lands are to furnish their share of the nation's increasing food requirements, there will be demands for expanded and accelerated range research. Before knowledge can be taught and applied, it must first be discovered. I would like to suggest in all friendliness to you who are engaged in range research that you avoid redundant and unnecessary repetition. For instance, I see no reason for continued experiments designed to emphasize stocking rates. It seems to me that the very considerable amount of excellent work which has already been done along this line has demonstrated that it is impossible under our climatic conditions to recommend a consistently proper rate of stocking expressed in acres per animal unit.

The commonly used terms "light", "moderate" and "heavy" describe the degree of use, but until we are able to predict the amount and seasonal distribution of rainfall, I refuse to accept anybody's statement that $X$ number of acres stocked with $Y$ number of cattle for $\mathrm{Z}$ number of months will result in moderate grazing or proper use. The emphasis should not be on the number of cattle, but the degree of use. Whether $\mathrm{X}$ acres should be stocked with more or less than $\mathrm{Y}$ cattle for more or less than $\mathrm{Z}$ months is not nearly as important as: 1. Recognizing the symptoms of overuse, and 2. Being prepared to take appropriate action when necessary.

Failure on either count will inevitably result in a depleted range and unsatisfactory cattle gains. The condition of the grass should tell the alert operator when it is time to either move or sell cattle until he gets his numbers in balance. I'm confident that every experiment station in the Great Plains has accumulated plenty of evidence to prove that overgrazing is unprofitable. Now let's concentrate on ways to make more money without overgrazing.

I suggest that we need more research with regard to concentrated pasture supplements. The amount and variety of commercial mixtures now being sold in competition with the standard cottonseed and soybean feeds are evidence of a demand for improved supplements to balance the seasonal deficiencies of range forage, and newly developed chemical compounds offer plenty of choices for experimental work.

The abundance of grain sorghums produced on the Great Plains in recent years has encouraged a number of ranchers to try to find a profitable use for them in winter rations for weaned calves on native grass. On our ranches, we are currently using a mixture of approximately three pounds of rolled grain, $3 / 4$ pound of 50 percent soybean meal, and $1 / 2$ pound of salt per head per day in self feeders. Our experience with a straight salt- 
meal mixture has not been satisfactory, and we find several advantages to this mixture over hand fed pellets:

1. Less shrink at weaning time.

2. It saves labor.

3 . We can winter more calves on the same amount of grass.

These advantages are more apparent with light calves (400 lbs. or less) than heavy calves. However, under ordinary circumstances, I consider it is poor judgment to buy a heavy calf to winter on grass. Since we generally winter from 1,000 to 1,500 calves, we try to use a simple and efficient ration. The one I mentioned can probably be improved, but in spite of some negative experimental evidence we think a limited amount of grain can be profitable under our conditions. We like to winter our calves good enough to have them ready to sell to a feeder by August if possible. In a dry spring we just keep them on feed until it does rain.
In speculating on the uncertainties of the future, one definite prediction can be made: range management will be an increasingly important factor in the success of a ranch operation. The investment will be too large, the profit margin too small, and the weather too uncertain to permit carelessness or inefficiency. The rancher will continue to need all the help he can get from the research scientist, the educator, and the field technician, in order to make the most efficient use of range forage.

\section{Our Range Society}

The American Society of Range Management has, since its organization in 1947, made important contributions to the science and art of grazing land management. Almost coincident with the Society's founding, the United States Department of Agriculture published the 1948 Yearbook of Agriculture, which was principally authored by members of the Society and devoted exclusively to Grass. That book is still an authoritative text. Members of the Society are continuing to explore every continent, gathering and disseminating information. The Society's Journal is an excellent source of current scientific and practical material.

I was converted and baptized (so to speak) into the Society at its third Annual Meeting in San Antonio in 1950. My fourteen years of membership have been the equivalent of a post graduate course in Range Management, under the tutelage of the best authorities in the field. The meetings and tours, the personal contacts and friendships I have formed, have been pleasant and profitable. I would recommend membership in the American Society of Range Management to any rancher who is interested in preparing for the challenges and opportunities of the future. 